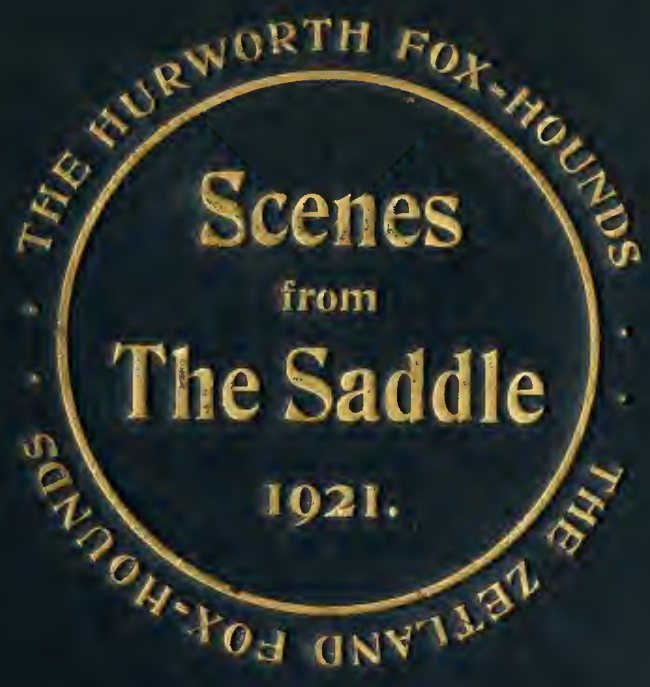

E. LLOYD PEASE. 
2 


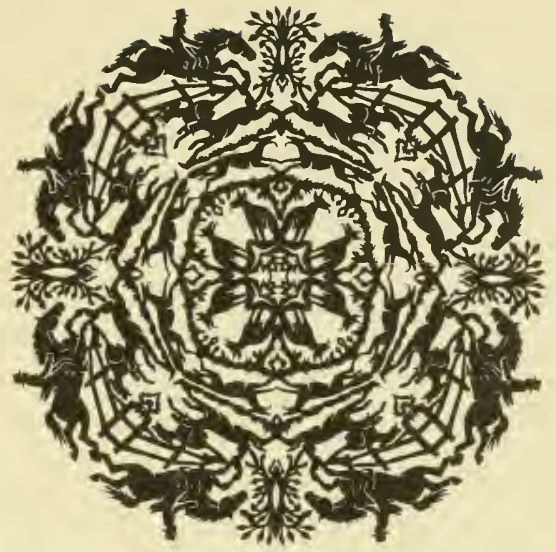

JOHN A.SEAVERNS 


\section{SCENES FROM THE SADDLE}





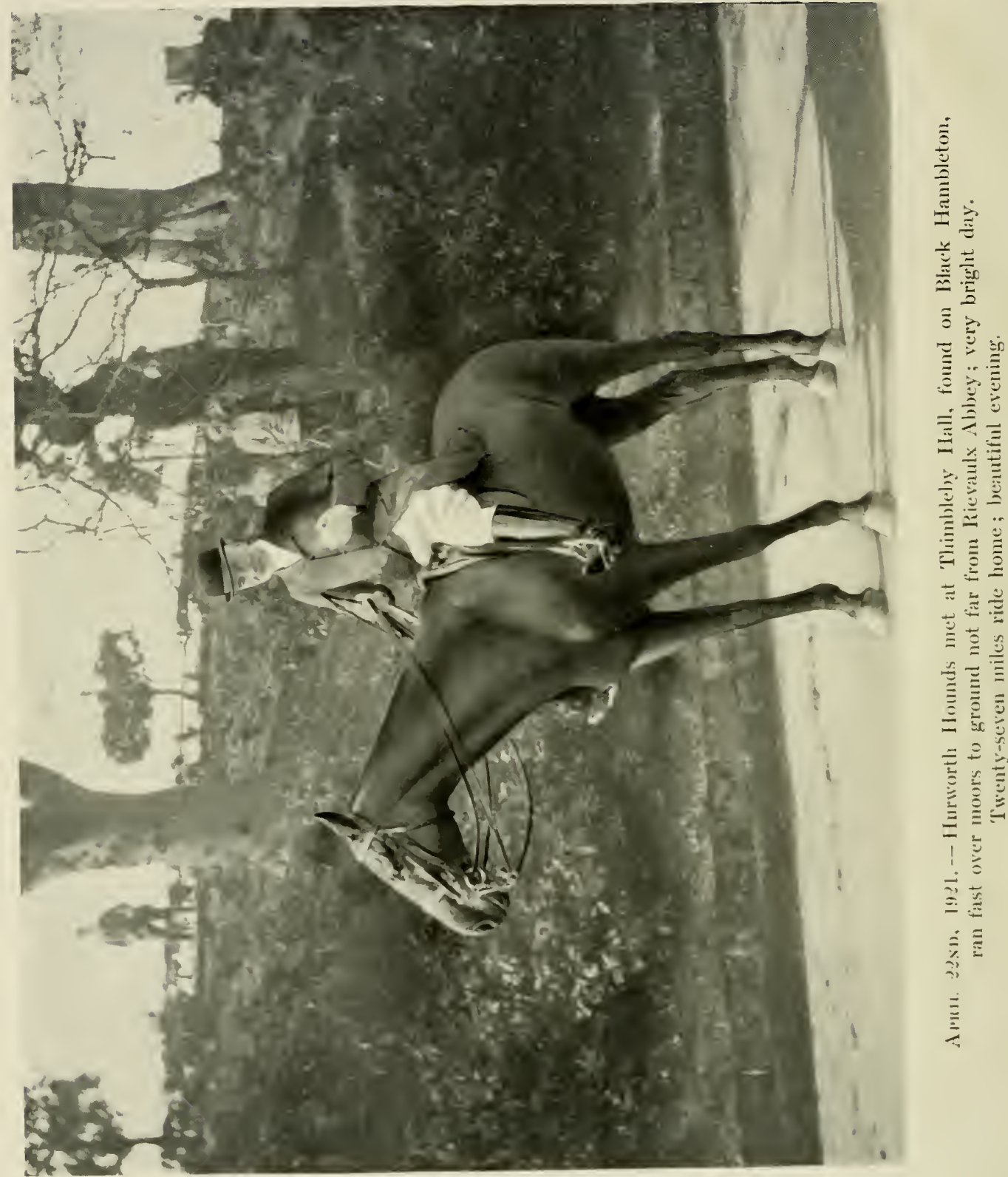


\section{SCENES}

\section{FROM THE SADDLE}

BY

E. LLOYD PEASE

LONDON :

ARTHUR L. HUMPHREYS,

I87 PICCADILLY, W.

I 92 I. 


\section{To the Reader.}

TO PRESERVE SONETHING OF THE DELIGHTFUL FEATURES ATTENDANT ON FOX-HUNTING FOR A FUTURE WHEN THE SCARLET AND THE QUAKER COAT MAY EQUALLY BE THINGS OF THE PAST, IS THE OBJECT OF THIS PAMPHLET, AND THE AIM OF ONE TO WHOM BOTH HAVE BEEN FAMLLIAR, BUT THE FOX-HUNTER WILL FIND NOTHING OF MOMENT THEREIN.

Hurworth Moor, Darlington, 1921. 


\section{SCENES \\ FROM THE SADDLE.}

THE physical pleasure arising from being on horseback and being in control of the partnership is probably the most general reason for devotion to hunting. To the huntsman it is the performances of his hounds individually. For a few it partakes of a form of society function, but this feature can only occur with the ultra-fashionable packs and is entirely absent from the smaller hunts, where the attraction is hunting and little else besides.

He who lives in a natural hunting district and through years of association knows every farm and byeway for miles round, has bred and broken his hunters to the third and fourth generation, such an one, if he is engrossed in business as his daily occupation, is probably he who gets at least as much satisfaction out of it as any one, and that is saying a great deal. A generalisation truly, but one based on forty years' experience. These few notes have been put together in appreciation of, and as a very brief expression of, the pleasures, mental and bodily, of forty seasons, and with a feeling that it may prove to be a reference to a national institution which may shortly cease to find a place.

There are comparatively many young women who hunt, but within the writer's experience hardly any young men. 'The war took a heavy toll, and the necessity of close application to professions or business under the present conditions of living has taken most of the rest. Of the men who hunt, the great majority of those who carry the burden of the expense are middle-aged or elderly, and although their activities will eventually be curtailed by age, taxation appears to be at the moment the more immediate foe to fox-hunting.

* * * * * * * * 


\section{SCENES FROM THE SADDLE.}

\section{The Rider.}

THE rider to a meet of an unfashionable hunt has in these days usually a solitary ride. Even with these lesser-known packs many of those who hunt regularly "motor" to the meet, and the habitual "rider on" is in so decided a minority that only infrequently does he pick up a companion on his way. A two hours' solitary ride, or it may be more, provides opportunity for cogitations and for changes in the details of the surrounding picture.

'There are various types of morning at nine o'clock in the winter months. For the weather-prospecting rider the dull, cold, windy and foggy morning is the least attractive. A thoroughly thick or thoroughly frosty morning puts hunting out of the question and raises no debate. A mild though wet outlook is encouraging, presenting as it does a prospect of a day of good scent. Few mornings are so bad as they may appear to be from the window, and many of poor appearance are reasonably good company on the way to the meet.

It is natural that in normal times the reflections presenting themselves should be heavy or light, dark or bright, in consonance with the surroundings of the way, but in these days of unprecedented trouble, to even the brightest morning there is looming behind a dark background. In such days the rider has to ask himself whether it were better that riders did not ride, to which question the natural speculation follows as to what alternative livelihood those of advanced age who are engaged in stable work would find if no longer employed in their trade. Such thoughts are dark and dreary companions for a pleasure outing.

'There are, happily, certain lighter speculations that can always occupy the rider. However many times he may have passed that way, some part of the road may place itself in a 


\section{SCENES FROM THE SADDLE.}

new light. Its direction and twistings and junctions bring up suggestions as to its history, and the date of its enclosure is suggested by the age of its hedges and hedgerow timber. Many roads have been originally trodden out in the lines of least resistance by beast or man at a far prehistoric date, and those leading to a river ford may be pictured as having an age equal to that of man himself.

Running in the same track for centuries the narrower lanes and byeways tend to cut deep into the surface, especially in hilly parts, where the road track forms a natural water-channel in wet weather. Along the sides of most lanes there may be seen indications that the track has varied from time to time, probably before the lane was definitely enclosed. It is a far cry to the Roman and pre-Roman roads from the slippery tarmacadamised highway of the present day, but to the rider the more he can tread the unimproved highways of the past and avoid the present the more pleasure he has in his journey.

Every old village has its charm. 'The rider, unlike the motorist, has time to notice details. 'There is much speculation to be had as to the date of individual houses from shape of their bricks, their differing thickness and colour; as to which of them may originally have come from abroad as the ballast of boats returning from exporting grain and hides. Beyond their possible name-termination of "ton" or "bury" in its various forms, or other terminations indicating the stockaded place, all village names must have an origin of more or less interest. Of their past strength nothing may now be visible, but a hardly discernible indication of a moated earthwork half hidden by farm buildings, but still sufficient to re-picture the past.

The rider when passing through the countryside, even if it be a district of small farms averaging less than a hundred acres, finds it strangely empty of human life, either in the villages, on the roads, or in the fields.

Into the midst of quietness fox-hunting brings a passing flash of colour, life, and excitement, and the feeling of the countryside is undoubtedly entirely favourable to it, and 


\section{SCENES FROM THE SADDLE.}

although farmers in increasing numbers own their farms, the percentage of those who object to hounds crossing their land is a very small one. The chief tangible cause for complaint is damage arising from loss of poultry by foxes, and although every claim for compensation that is put forward may be thoroughly genuine, they on the whole probably do not cover the losses sustained. 'This was eminently the case during the war years, when out of consideration for the absence of most of the members of hunts, hardly any claims were presented. 'There are districts in which hunting appears to be indigenous, and others where it is an artificial adjunct, in varying degrees, and it is possible that in the latter some of these reflections may not wholly apply.

The rider during his journey will probably know moments of contemplation and apprehension as to the possible experiences of the day. 'There is an element of anticipatory excitement, almost subconscious, attached to fox-hunting which, although it is the impelling force of the moment, and without which the rider would stay at home, may become unpleasantly acute. Will hounds run over a line of country bristling with difficulties that will place too great a strain on a small stock of courage? Or worse, will one not really formidable obstacle at the beginning be shirked and the hunt be lost to view in consequence for what appears to be an interminable length of time, or for the rest of the day?

There is, however, one consoling thought always at command, that it is only requisite or possible to deal with one difficulty at once, one fence at a time, out of the fifty imaginary obstacles that crowd together in the picture; the daily path of life in miniature. 'The rider's thoughts are apt to turn in a natural sequence to the horse, his all-important partner. If he is old and tried, but not too old, well and good; if young and unknowing, a certain amount of apprehension is justified. 


\section{SCENES FROM 'THE SADDLE.}

Grey and green in colourless tone

Country-side and tree,

On, on, wending alone,

Mile on mile, but with thoughts that are free

From cares of the day, life's penalty.

Red and brown homesteads, restful, small

Byre and pond and well,

Sleep kind sleep over all,

'The touch of peace with enchanting spell

And winter's calm, that ferered thoughts repel.

Mile on mile, villages remote,

Effortless, asleep,

Where dream-lives seem to float,

Phantom-like, on 'Time's unruffled deep,

'I'o those who storm-tossed watch-hours keep.

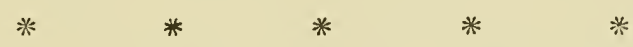

Man and horse, dark and distant hills,

Winding way and cloud,

Peace, peace, the eye-range fills ;

Pray man in haste may not have wrought his shroud

In his weaving, of his deftness proud.

Man and horse, dark and heavy thought,

-World-wide moil and pain-

Eclipsed, man's vision caught

Of work's reward, shall he all regain?

Nore, hath he aptitude to attain?

In these dark post-war days of 1921 such thoughts are constant and unavoidable companions ; it is to be hoped that a bright future cometh in which the present darkness will be unrealisable. 


\section{The Horse.}

$T^{O}$ keep a reasonably satisfactory position in a good run, and body, whilst slow runs and the ordinary experiences of a day's hunting have a sufficiently absorbing interest to secure the banishment of business and other cares. 'There are some who hunt because it is their winter employment; these are perhaps inclined to be super-critical of the "sport" shown. There are others whose day with hounds is wedged in where possible among business engagements. These are inclined to be uncritical ; every day is enjoyed.

It is not possible to strike a balance between the pleasure experienced by the man always well in front on a good horse, whether purchased at five hundred or at fifty pounds, and that of the man further behind, who may be teaching the rudiments of self-preservation to a horse of his own breeding. Possibly each has the experience suited to his temperament; the one probably does not possess the patience to wait six years for a foal to mature into the made hunter of the class he requires, or the latter the ability to be consistently in the forefront, and each draws his own satisfaction from the day.

'The well-bred horse is, as a class, keen and resentful of restraint. 'This is only what might be expected from his race history of many generations, but he is as a rule very amenable to training. 'The horse, on the other hand, whose pedigree largely includes ancestors who have been driven by the voice in the plough or by whip in the cart has naturally a different disposition. The one is carried forward by inbred emulation, the other without the same natural inclination to compete. He who rides young horses will have to suit his actions to his mounts. Whereas with one horse he will have to exercise much patience in endeavouring to teach self-restraint, to get 


\section{SCENES FRON THE SADDLE.}

the other to carry itself compactly and in balanced form and to respond immediately to control, may be no less exacting to the temper. The man who essays to teach horses control of mind and body must have a fair allowance of these qualities himself and secure a firm but kindly control.

A liorse, whatever his breeding may be, if he has not an alert brain, or if alert is carried away by excitement, will never make a safe mount. In a hunting country of small farms, which in itself implies small fields, the fences are numerous and have many varieties of form. They generally are associated with a ditch so overgrown with dead grass as to be barely distinguishable; these are troubles which a horse with brains quickly learns to surmount, but which remain a constant source of risk to the slower-witted hunter. The quality next in importance in a good hunter to intelligence is perhaps good manners, but these are of little value without courage, a light heart, and a good constitution; these, combined with a blessed immunity from lameness, will bring his rider safely home in the evening without being appreciably tired by the fifty miles he may have covered.

\section{The Foal.}

YE of free and happy grace

Frisking round your mothers,

Ye of long-descended pace,

Racing with your brothers

In the pasture fringed with trees,

Born to life of high emprise.

Knights in making, skill your goal

Dedicated knights as foal.

The 'l'wo and 'Three-year-old.

YET untroubled by the rein, Saddle, bit, or stable,

Bite and kick in playful vein,

Child of myth and fable. 
SCENES FROM THE SADDLE.

Pedigreed from steppe-life dim

Ye light of heart, tough of limb, Tail and mane as pennons flow, Speed and stature perfect grow.

The Four-year-old.

Is deep-going gallop light

Brimming o'er with keenness, With your rider never fight,

Own no vice or meanness,

Enter life and learn thy part,

Master all the hunter's art,

Know all tricks the fences hold,

Hail! friend! hunter ! hero bold ! 
SCENES FROM 'I'HE SADDLE.

\section{The Fox.}

B Y chase alone thy daily life is lived,

B By chase maybe thy doomèd death is met,

Unless thy cunning and thy pace reprieve

'Till age and time enwrap thee in their net.

By man's decree thou livest thy brief day, By man is set the death that thou shalt die,

Yet oftentimes thou cheatest his desire,

His slave by birth, his wish thou dost deny.

How ends thy life-account of joy and pain?

'The joys of cub-hood in the quiet wood,

The wider joys of life, its months or years

Doth wild-life fate out-balance all the good?

'This minor riddle in the great riddle of life cannot be solved by the expedient of merely chasing and not killing. 'The hunting instincts of the hound demand at least some token of success, and in the view of most huntsmen this under the conditions governing the chase comes all too seldom. Where foxes are at all numerous, to kill a fox with hounds is a difficult task, for a fox that is being run and is in danger is frequently able to turn the attention of the pack to another member of his tribe, and so to obtain a much-wanted respite. A fox in the prime of life, unless he is found far from home at mating time, has a very good chance of escaping his enemies. Cub-hood and old age are the danger periods of the fox. 


\section{SCENES FROM THE SADDLE.}

Hast thou observed the fox that many times has sped Before the pack, break cover, like an athlete in a race, High strung in mind and limb, and by ambition fed To joy at one more chance to prove his skill and pace?

Or at some corner thick, on tip-toe seen him steal, All nerves and wire with grace of cat, give backward glance Of half disdain, at sounds of misdirected zeal Unravelling his track-a day of poor scent perchance? 


\section{Cub-hunting. An Opening Day.}

CUB-HUN'TING in autumn hath charms of its own,

C That but for a short time re-visit the earth,

'Till darkness of winter o'er all things is thrown,

'That grace with their presence a new season's birth.

Night dews, like sleep-tears each green blade adorn, Soft breath and sweet smile steal o'er the world's face,

Pearl grey and rose tint speak opening morn,

Sing to the horseman the charms of the chase

As early he rides where the note of the horn

Wakes Reynard from sleep, to enter life's race;

'Tell young hound and cub to strife they were born,

'The value in life of boldness and pace.

A picture that's new, in a frame that is old, With new horses, new hounds, new foxes, old friends, New pleasures, and those of past seasons re-told, Cub-hunting to life living scenery lends.

It is early in September that the young fox first learns that he has enemies, that his sanctum is liable to invasion, and it is then that the young hound's instinets have their first opportunity in life. 'To take advantage of the lingering dews and coolness of night, cub-hunting must arouse the woods in the early morning hours. It ean only be in happy and natural surroundings in a woodland district, for where there are cornlands no hunting can take place until later in the year, when all the crops have been reaped. The morning lights and the woodland colours of September form a beautiful picture for the early-rising rider's enjoyment. The woodlands and moorland pastures are also the hunting-field of the last days of the season amid the delightful setting of the late days of April and early May. 


\section{SCENES FROM THE SADDLE.}

\section{Hunting Days. \\ Mid Season.}

KNOW ye the winter day cold and drear,

K Know ye the hunting day hanging with storm,

When driving the rain and eutting the wind,

'The day fast fading and never a find,

'Till at length hounds own to a fox in a whin,

'Then a wait unending for the fox to clear?

Know ye the mirage of a bright-lit home,

Whilst wind from the north and icy shower

Seem to hint at hunting being empty and vain,

Unfit for a man with a reasoning brain,

'The sense of it all, where doth it appear?

Is pleasure consistent with coldness and gloom?

Long mimutes of lead crawl hearily by, Why go not? but why stay? why?

Ho! for the day when the fox goes away Straight from the whin in the morning.

When men are still blest

With nerves at their best

All spick in searlet adorning.

Ho! for the day when the fox goes awity

Leaving a good scent, a hot one,

No time for a gate

If you'd not be late,

'The zest of hunting has got one. 


\section{SCENES FROM THE SADDLE.}

Ho! for the find when the fox knows his mind.

'The risk? - he gallantly meets it ;

"Tis a race, a race

'Twixt his and hounds' pace ;

His death?-for this time he cheats it.

Ho! for a find when a scent-bearing wind

Blows fresh, is steadily blowing,

The country well soaked,

In shadow well cloaked,

The fences all fair,

No "wire-beware-_"

O'er a line that is known, wants knowing.

Ho! for the day when the fox goes away

Straight from the whin in the morning. 


\section{To Reynard \\ The End of the Season.}

'MID charm of the sunlight on dark-tonèd fir-tree, $M$ Of sunlight of spring on thick-carpeted glade, Dies the note of the horn on echoing woodland, Dies death's haunting call, and lives freedom for thee.

Moves grey horse and red coat, 'mid brown, amber, bright green Of moorland, of beech leaf thick fallen, and field; Then silence; a charm falls on hound, horn, and huntsmen, We hope thou hast peace now thy foes quit the scene.

We grieve if in summer when full-leaved thy stronghold, And dark o'er the stream the hazel bush hangs, Green is the bracken and fruiting the bramble, 'The chase still alarms thee, thy warm blood runs cold.

A grey-mounted huntsman glints pale in the deep shade, And swift-moving hounds thread the tall waving brake, A note of the horn whene'er the wind whispers;Do phantoms as these thy short rest-time invade?

'Mid charm of the evening and moorland and wide view Good-byes we exchange with hill, valley, and wood, Ere home, for the last time through lowland long shadedln peace may you rest, for we owe much to you. 
SCENES FROM THE SADDLE.

\section{A View.}

HARK! a holloa! a holloa! but none too clear,

$H$ Yet the knowing old hunter cocks an ear,

Hark! a holloa again!'tis a whipper-in

With a note that carries over woodland and whin.

The hunt in the corner no longer need wait,

Both horses and men in a fidgety state,

But the covert is thick, the covert is wide,

It is a long way round and ne'er a cross ride

'To lead to the point where the first whip stood,

When he saw old reynard break out of the wood.

'There's this way and that way, but which is the best?

The way reynard is heading can only be guessed,

But stay not-it is foolish to linger in doubt,

The way to be wise is to go and find out.

In time!--but no more, for the pack is away

With chestnut and brown and conspicuous grey,

With riders in pink and mufti and black,

In rivalry keen, too close in its track.

In time-but no more, to keep well in touch-

Not one of the few the first flight to reach.

You can hunt with your head or a fear-nothing heart, You will need them combined if you make a slow start, And a good horse, and fast, if you'd keep hounds in view When they make the great running they sometimes do. Then 'tis the bold and young and light have the place; But there's joy e'en behind in the scenes of the chase.

When the fields they are small and fences come thick, A fence with a rail, or the on-and-off trick, 


\section{SCENES FROM THE SADDLE.}

With a ditch full of grass on the taking-off side, A grip in the field that just comes in the stride, Then ho! for the horse that knows his work well, Changes feet in a flash, does not bungle or dwell, Lo! scarlet and black are down with a roll, And fences and ditches are taking their toll. Still it's galloping on and galloping all, And each one is taking his chance of a fall, And the first becomes last, but his glory remains, For hunting with heart is more than hunting with brains. 'Then here's to the gallop that makes the field one, He who dazzles with dash, he who joins in the run. 


\section{Homeward.}

WHEN the way is long and lone,

When the evening falleth,

When the hunting day is done,

When the lapwing calleth,

Soft the breeze and low the light

Thrown across earth's dial face,

Pointers flung by coming night,

Warning of its dark embrace.-

Linger-'tis no hour for speed,

Time, in jewelled setting dwells,

From his urgent day-course freed-

The charm of eve impels.

\section{Along the Road.}

When homeward at even 'neath the bright crescent moon, Neath the quiet star realm with its cloud in the west,

'Tis then that the blood of forefathers uprising Saith, 'The life of the hunter remaineth the best.'

When the peewit and owl to the fast-falling night Send far-floating notes in their flights o'er the field To the man and his horse and to all things foregatheredA past, yea, a far past, to the mind stands revealed.

Up the ages as hunter he won him his place On the high throne of life, with serfs at his feet, 'Midst his work and his toiling, a whisper comes claiming A fight with the fierce, a race with the fleet. 


\section{SCENES FROM THE SADDLE.}

\section{Over the Plain.}

Ho! for the song of the evening ride When home from hunting returning;

Ho! for a song when the shadows are long, 'That early seek rest on the valley's breast, And lie so light as they wait for the night 'That the fair plain smiles like a maid caressed.

Ho! for the way the vanishing day, 'That ere it meets death, with its sweetest breath, Gives a kiss which says, 'We both go our ways,' And winds round the hunter its airy wreath.

Ho! for the song as we canter along O'er the old grass fields, and the turf that yields 'To the feet, to the feet, with even beat, Or jog on the lane with its thorny shields.

Oh! for the song of the evening tide When home from hunting returning.

\section{By the River.}

There's a spirit in the soft light Of a rich-hued autumn day, 'There's a spirit in the bright tints Of the dead leaves by the way, 'There's a spirit in the landscape Melting in the sun's low ray.

These are joyous, but the river Shining neath a peaceful sky, 


\section{SCENES FROM THE SADDLE.}

With its note of 'Ever,' 'Ever,'-

Bier of leaves that change and die-

Hath for men a mystic spirit

Brooding whilst the seasons fly.

Deathless voices, universal,

Blending for his infant mind,

Life's fair rhythm, time's dread message,

In an anthem for mankind-

Come, trot on! 'tis getting darker,

And there is a shrewdish wind. 




